\title{
COMMENTARY
}

\section{Anaemia and its treatment in neurologically critically ill patients: being reasonable is easy without prospective trials}

\author{
Andrew M Naidech* \\ See related research by Diedler et al., http://ccforum.com/content/14/2/R63
}

\begin{abstract}
Most healthy humans have a haemoglobin concentration of 12 to $15 \mathrm{~g} / \mathrm{dL}$ and most intensivists now transfuse packed red blood cells for haemoglobin $<7 \mathrm{~g} / \mathrm{dL}$. Higher haemoglobin is associated with improved intermediate and clinical outcomes after subarachnoid hemorrhage (from ruptured brain aneurysm) or neurotrauma. An observational study in a recent issue shows that higher haemoglobin was associated with better functional outcomes in patients with spontaneous intracerebral haemorrhage; few patients received a packed red blood cell transfusion, so it is not known if that treatment is better than the disease. The mechanism of anaemia's purported impact on outcome is unclear, although altered metabolism in brain tissue that is sensitive to reduced oxygen delivery is plausible. These data may intensify the differences of opinion between intensivists: whether neurologic patients are better served by higher haemoglobin and potentially by more packed red blood cell transfusion, or simply need to be studied more in prospective clinical trials, remains unclear.
\end{abstract}

\section{Introduction}

The previous issue of Critical Care contains a report associating more severe anaemia with worse outcome after intracerebral haemorrhage. [1] These data are analogous to published reports in subarachnoid hemorrhage and traumatic brain injury that link more severe anaemia with worse outcomes.

\section{Anaemia and transfusion in critical illness}

The traditional goal for packed red blood cell (PRBC) transfusion was traditionally $10 \mathrm{~g} / \mathrm{dL}$, and revised down

*Correspondence: a-naidech@northwestern.edu

Northwestern University Feinberg School of Medicine, Department of Neurology, 710 N Lake Shore Drive, Eleventh Floor, Chicago, IL 60611, USA to $<7 \mathrm{~g} / \mathrm{dL}$ [2] with the exception of acute coronary syndromes or acute resuscitation. Unfortunately, there have been no large, prospective trials of PRBC transfusion in patients specifically with neurologic disease.

\section{Anaemia in the neurologically critically ill}

Anaemia is associated with worse outcomes in nontraumatic subarachnoid hemorrhage (ruptured brain aneurysm) [3]. Preventing brain hypoxia might be important to reduce the incidence and severity of cerebral infarction from vasospasm, and PRBC transfusion in that setting leads to improved markers of brain tissue function on positron emission tomography [4]. In patients with traumatic brain injury, brain oxygen monitors may show low brain oxygen tension that responds to PRBC transfusion [5]; the BOOST2 study is planned to assess if brain oxygen tension-guided therapy improves outcomes. A sub-study of the Transfusion Requirements in the Critical Care trial found no apparent effect of goal haemoglobin concentration on functional outcomes after neurotrauma [6].

Why would anaemia after intracerebral haemorrhage matter? Intracerebral haemorrhage does not lead to vasospasm, but cerebral infarction can be found on magnetic resonance imaging scans [7] and this may impact outcomes. There is probably not hypoxia around the clot [8], but there may be altered metabolism for a period of several days [9].

Remarkably few patients received a PRBC transfusion in the cohort, usually for surgery. The nadir haemoglobin for patients with poor outcome $(11.5 \mathrm{~g} / \mathrm{dL})$ was above the usual trigger for transfusion, so these data are of limited usefulness in determining when a PRBC transfusion should be given.

What one should think of anaemia in the neurologically critically ill is likely to depend on one's preconceived notions. If you are convinced that anaemia in the NeuroICU is linked to worse neuronal function, cerebral ischemia and poor outcome, you will probably (successfully) justify keeping your trigger for PRBC 
transfusion at $<10 \mathrm{~g} / \mathrm{dL}$. If you are convinced these observational data simply show sicker patients have worse outcomes despite the statistical correction for older age and larger haemorrhage size, then you will probably (successfully) justify keeping your trigger for PRBC transfusion at $<7 \mathrm{~g} / \mathrm{dL}$. If you have a specific physiologic trigger (reduced brain oxygen tension, increased oxygen extraction fraction on positron emission tomography, and so on), few will argue with you. As Benjamin Franklin said, 'So convenient a thing it is to be a reasonable creature, since it enables one to find or make a reason for everything one has a mind to do.'

\section{Conclusion}

Anaemia is generally associated with worse outcomes in neurologically critically ill patients. Whether the outcome can be improved by more frequent use of PRBC transfusion remains unclear.

Abbreviations

$\mathrm{PRBC}=$ packed red blood cell.

\section{Competing interests}

AMN has received grant support for a prospective, randomized trial of goal haemoglobin in patients with subarachnoid hemorrhage from NovoNordisk and the Neurocritical Care Society and the Northwestern Memorial

Foundation. That study is over and the results are under peer review. AMN has previously published on the topic of anaemia and subarachnoid hemorrhage, as cited in the article under discussion; this may be perceived as a non-

financial competing interest.

Published: 12 May 2010
References

1. Diedler J, Sykora M, Hahn P, Heerlein K, Scholzke M, Kellert L, Bosel J, Poli S, Steiner T: Low hemoglobin is associated with poor functional outcome after non-traumatic, supratentorial intracerebral hemorrhage. Crit Care 2010, 14:R63.

2. Hebert PC, Wells G, Blajchman MA, Marshall J, Martin C, Pagliarello G, Tweeddale M, Schweitzer I, Yetisir E: A multicenter, randomized, controlled clinical trial of transfusion requirements in critical care. Transfusion Requirements in Critical Care Investigators, Canadian Critical Care Trials Group. N Engl J Med 1999, 340:409-417.

3. Naidech AM, Jovanovic B, Wartenberg KE, Parra A, Ostapkovich N, Connolly ES, Mayer SA, Commichau C: Higher hemoglobin is associated with improved outcome after subarachnoid hemorrhage. Crit Care Med 2007 35:2383-2389

4. Dhar R, Zazulia AR, Videen TO, Zipfel GJ, Derdeyn CP, Diringer MN: Red blood cell transfusion increases cerebral oxygen delivery in anemic patients with subarachnoid hemorrhage. Stroke 2009, 40:3039-3044.

5. Smith MJ, Stiefel MF, Magge S, Frangos S, Bloom S, Gracias V, Le Roux PD: Packed red blood cell transfusion increases local cerebral oxygenation. Crit Care Med 2005, 33:1104-1108.

6. McIntyre LA, Fergusson DA, Hutchison JS, Pagliarello G, Marshall JC, Yetisir E, Hare GM, Hebert PC: Effect of a liberal versus restrictive transfusion strategy on mortality in patients with moderate to severe head injury. Neurocrit Care 2006, 5:4-9.

7. Prabhakaran S, Gupta R, Ouyang B, John S, Temes RE, Mohammad Y, Lee VH, Bleck TP: Acute brain infarcts after spontaneous intracerebral hemorrhage: a diffusion-weighted imaging study. Stroke 2010, 41:89-94.

8. Zazulia AR, Diringer MN, Videen TO, Adams RE, Yundt K, Aiyagari V, Grubb RL, Powers WJ: Hypoperfusion without ischemia surrounding acute intracerebral hemorrhage. J Cereb Blood Flow Metab 2001, 21:804-810.

9. Zazulia AR, Videen TO, Powers WJ: Transient focal increase in perihematomal glucose metabolism after acute human intracerebral hemorrhage. Stroke 2009, 40:1638-1643.

doi:10.1186/cc898

Cite this article as: Naidech AM: Anaemia and its treatment in neurologically critically ill patients: being reasonable is easy without prospective trials. Critical Care 2010, 14:149. 